\title{
Public policy of over indebtedness regulation: a comparative study between Brazil and France
}

\author{
Daniele P. Blattner (IC)
}

\section{Abstract}

The considerable increase in income, the growth of credit supply and encouraging consumption promoted by the efforts in advertising create unfavorable conditions for consumers: the commitment of their income against the debt. The absence of mechanisms for prevention and treatment of this problem, ultimately aggravate the process, allowing a space for the emergence of the phenomenon of over indebtedness. The work presented thus has the mission of showing the ways that the consumer rights must be drawn to deal with this phenomenon.

Key words: Over indebtedness, Consumers, Regulation

\section{Introduction}

Over indebtedness means compromising the income of the consumer of 'good faith' in a higher proportion than this consumer is able to meet the payment without an external aid. The over indebtedness condition creates a situation in which it undertakes the guarantee of existential minimum for consumers, hampering the guarantee of human dignity.

\section{Results and Discussion}

It is evident, therefore, that the over indebtedness phenomenon should be avoided from the preventive law, and when already installed, must be properly handled from the corrective law. The work presented thus has the mission of showing the ways that the consumer rights must be drawn to deal with this phenomenon. The method used for this is the analysis of comparative law, based on the example of French law, as well as the Bill No. 283 of 2012 from the Federal Senate.

\section{Conclusions}

The minimum existential concerns all the necessary resources to ensure people a dignified existence. Such right can be secured via state intervention (right of a positive nature) and also through non-intervention (negative nature right).

Consumption opportunities, advertising and the supply of credit, however, can be impediments to guarantee the existential minimum. Consumers, even in good faith, that is, intended to honor all of its debts, end up falling into the credit trap easily and, when they realize they are completely indebted in some cases, in such a way that it makes it virtually impossible to get rid of that debt without the use of support.

In such cases, not only the existential minimum, such as human dignity are left aside. The acquisition of key resources to ensure minimum quality of life and well-being come to stay in the background, but beyond that, people start to lose out on other aspects, such as the relationship with friends, family and even themselves.

When this level is reached, it is evident the need for the existence of law governing the variables that lead to this condition of over indebtedness and also to allow those already over indebted out of this uncomfortable situation. An example of legislation that deals with exactly this issue, covering many of the topics is the French Consumer Code. It establishes preventive and corrective measures relating to advertising, the availability of credit and over indebtedness.

\section{Acknowledgement}

l'd like to thank professor Vedovato for his dedication to this research and PIBIC for sponsoring this project.

\footnotetext{
${ }^{1}$ COSTA, Geraldo de Farias Martins da. Superendividamento: a proteção do consumidor de crédito em direito comparado brasileiro e francês. São Paulo: TR, 2002.

2 MARQUES, Claudia Lima. Sugestões para uma lei sobre o tratamento do superendividamento de pessoas físicas em contratos de crédito ao consumo. Revista do Direito do Consumidor, São Paulo: RT, n 55, p.11-52, jul.-set., 2005.

${ }^{3}$ MARQUES, C. L. (Org.); CAVALlAZZI, R. L. (Org.) . Direitos do Consumidor endividado: Superendividamento e Crédito. 1. ed. São Paulo: Revista dos Tribunais, 2006. v. 1. 400p .

4 MARQueS, C. L. ; LiMA, C. C. ; BeRtonCEllo, K. Prevenção e tratamento do superendividamento. Cadernos de Investigação Científica. 1. ed. Brasília: DPDC/SDE, 2010.

${ }^{5}$ RODRIGUES JUNIOR, Otavio Luiz. Conselho francês rege casos de superendividamento. Revista Consultor Jurídico, 2013.
} 